tekhnolohii u pochatkovykh shkolakh Ukrainy (19592018 rr.): monohrafiia [The development of educational technologies at primary schools of Ukraine (1959-2018): monograph]. Ternopil, 162 p. [in Ukrainian].

18. Chaikovska, H., Yankovych, O., Levchyk, I., Kuzma, I. \& Rozhko-Pavlyshyn, T. (2021). Formation of sustainable development competencies in primary school children. Journal of Education Culture and Society, No. 2, pp. 341-360. doi: 10.15503.jecs 2021.2.341.360 [in English].

19. Tereshchuk, H. V., Kuzma, I. I., Yankovych, O. I. \& Falfushynska, H. I. (2018). The formation of a successful personality of a pupil in Ukrainian primary school during media education implementation. Cloud Technologies in Education. Proceedings of the 6th
Workshop CTE 2018 (Kryvyi Rih, Ukraine, December 21, 2018) / Eds. Kiv, A. E., Soloviev, V. N. CEUR-WS.org, online, pp. 145-158. Available at: http://ceur-ws.org/Vol-2433/paper08.pdf(Accessed 7 Nov. 2021). [in English].

20. Yankovych, O. I., Chaika, V. M., Ivanova, T. V., Binytska, K. M., Kuzma, I. I., Pysarchuk, O. T. \& Falfushynska, H. I. (2018). Technology of forming medialiteracy of children of the senior pre-school age of Ukraine. Cloud Technologies in Education. Proceedings of the 6th Workshop CTE 2018 (Kryvyi Rih, Ukraine, December 21, 2018) / Eds. Kiv, A. E., Soloviev, V. N. CEUR-WS.org, online, pp. 126-144. Available at: http://ceur-ws.org/Vol2433/paper07.pdf (Accessed 7 Nov. 2021). [in English].

Стаття надійшла до редакції 27.09.2021

УДК 37.014.6:378.046-021.68

DOI:

Броніслава Ренькас, кандидат педагогічних наук, професор кафедри суспільно-гуманітарних дисииплін

Комунального закладу “Житомирський обласний інститут післядипломної педагогічної освіти” Житомирської обласної ради

\title{
ОСОБЛИВОСТІ ВПРОВАДЖЕННЯ ВНУТРІШНЬОЇ СИСТЕМИ ЗАБЕЗПЕЧЕННЯ ЯКОСТІ ОСВІТИ У ЗАКЛАДІ ПІСЛЯДИПЛОМНОЇ ПЕДАГОГІЧНОЇ ОСВІТИ
}

Стаття присвячена проблемі управління якістю освіти у закладі освіти, акиентовано увагу на використанні сучасних методів забезпечення якості освітньої діяльності закладу післядипломної педагогічноі освіти. Розглянуто елементи політики внутрішньої системи забезпечення якості освіти. Охарактеризовано набір прочедур впровадження системи забезпечення якості освіти у закладі післядипломної освіти.

Ключові слова: якість освіти; якість освітньої діяльності; управління якістю освіти; внутрішня система забезпечення якості освіти закладу післядипломної педагогічної освіти.

Jim. 8 .

Bronislava Renkas, Ph.D. (Pedagogy), Professor of the Social and Humanitarian Branch of Science Department of Communal Educational Institution "Zhytomyr Regional In-Service Teachers' Training Institute"

\section{PECULIARITIES OF IMPLEMENTATION OFTHE INTERNALSYSTEM OF QUALITY ASSURANCE IN EDUCATION IN THE IN-SERVICE TEACHERS'TRAINING INSTITUTE}

The article is devoted to the problem of quality management of education in an educational institution; the emphasis is on the use of modern methods of ensuring the quality of educational activities of the In-Service Teachers " Training institution. The peculiarities of education quality management as a leading idea of educational institution management are outlined.

The essence of the concepts "quality of education", "education quality management", "quality management system" is analyzed. The elements of the policy of the internal system of quality assurance of education are considered. The main principles on which the internal system of quality assurance of postgraduate pedagogical education is based as an element of policy are formulated. It is established that an essential step in understanding the policy of the internal system of quality assurance of education is to determine the purpose and main goals that the system should be guided by. The main tasks of the internal system of quality assurance of In-Service Teachers' Training institution as its intentions and orientation are outlined. Their place and role in the structure of the document, which should be the provisions of the internal quality assurance system of education in the educational institution, are determined

A set of procedures for the implementation of the system of quality assurance of In-Service Teachers'Training

(C) Б. Ренькас, 2021

146 


\section{ОСОБЛИВОСТІ ВПРОВАДЖЕННЯ ВНУТРІШНЬОЇ СИСТЕМИЗАБЕЗПЕЧЕННЯ ЯКОСТІ ОСВІТИ У ЗАКЛАДІ ПІЛЯДИПЛОМНОӤ ПЕДАГОГІЧНОЇ ОСВІТИ}

institution by means of which the policy of the system is implemented, is characterized. Procedures are determined by the characteristics of the institution, are a set of interrelated work to achieve the planned result. It is emphasized that quality assurance of education is a separate procedure in building an internal system of quality assurance of education of postgraduate pedagogical education, the purpose of its separation is the peculiarity of the implementation of the main processes - the quality of management processes and the quality of the main processes for the organization of refresher courses.

The requirements to the group of information support procedures, which are determined by the licensing conditions of educational activities in the In-Service Teachers' Training institution, are taken into account.

Attention is paid to the procedures for the development of general and professional competencies of pedagogical and scientific-pedagogical employees of the In-Service Teachers' Training institution as a component of the system of internal quality assurance of education.

Keywords: quality of education; quality of educational activity; management of quality of education; education quality assurance internal system of In-Service Teachers' Training institution.

П остановка проблеми. Одним із головних завдань управління закладами післядипломної педагогічної освіти $€$ ефективне управління якістю освіти та якістю освітньої діяльності. 3 огляду на це важливим стає впровадження внутрішньої системи забезпечення якості освіти закладу післядипломної педагогічної освіти.

Проблема побудови та впровадження внутрішньої системи забезпечення якості освіти у закладі післядипломної педагогічної освіти нині набула особливого значення. Це пов'язано з тим, що у вітчизняній законодавчій базі з питань освіти вимога щодо побудови системи забезпечення якості освіти у внутрішньому середовищі закладу освіти, розроблені методичні рекомендації для запровадження такої системи для дошкільної, загальної середньої освіти. На цій підставі виправданою є увага до впровадження такої системи у закладі післядипломної педагогічної освіти.

Зрозуміло, що особливості функціонування та розвитку сучасних закладів післядипломної педагогічної освіти зумовлюють особливості впровадження внутрішньої системи забезпечення якості освіти в них. У зв'язку з цим, важливо виокремлення політик i процедур як спрямовуючих елементів такої системи, моделювання на їх основі структури 3 урахуванням специфіки освітньої діяльності закладу післядипломної педагогічної освіти.

Аналіз останніх досліджень і публікацій. Дослідження якості освіти, управління нею набули особливого значення в період реформування системи освіти. У вітчизняному науковому просторі осмислення зазначених процесів представлено упрацях В. Андрущенка, В. Вікторова, I. Зязюна, Т. Лукіної, В. Лутая, С. Сисоєвої та ін. Інтерес вітчизняних науковців простягався від соціально-філософського осмислення до пропозиції шляхів забезпечення управління якістю освіти.

Якість освіти визначається як соціальна категорія; рівень забезпечення очікувань учасників освітнього процесу; рівень досягнення цілей і завдань освіти; рівень знань і вмінь, розумового, морального і фізичного розвитку тих, хто навчається; рівень забезпечення освітньої діяльності освітнім закладом [4].

Поряд $з$ термінологічним становленням поняття “якість освіти”, його законодавчим унормуванням, відбулося становлення поняття “управління якістю освіти”. Оскільки якість освіти залежить від багатьох взаємопов’ язаних факторів (матеріально-технічного, соціального забезпечення та ін.), а також професіоналізму, професійної компетентності педагогів, продуктивності взаємодії суб'єктів педагогічної діяльності та ін. [4], очевидно, що управління якістю освіти набуває особливої актуальності.

Т. Лукіна підкреслює значущість процесу управління якістю освіти, оскільки воно $є$ специфічним видом суспільної діяльності, що спрямована на підтримку та поліпшення якості й результативності функціонування галузі загалом та загальноосвітнього, культурного та професійного рівня тих, хто навчається [3].

Досить поширеним є визначення системи управління якістю, яка трактується як сукупність взаємопов'язаних та/або взаємодіючих елементів організації, які дають змогу спрямовувати та контролювати діяльність організації щодо якості [8]

На цій підставі є висновки, згідно 3 якими внутрішню систему забезпечення якості освіти закладу освіти можливо розглядати як множину взаємопов'язаних та / або взаємодіючих елементів закладу освіти, які дають змогу спрямовувати та контролювати його діяльність щодо забезпечення якості освіти [5].

Побудова внутрішньої системи забезпечення якості освіти у закладі освіти, таким чином, передбачає урахування елементів, які спрямовують діяльність закладу, та елементів, які контролюють іï, у їх взаємозв'язку та взаємодії. Особливості діяльності закладів післядипломної педагогічної освіти обумовлюють специфіку побудови та впровадження такої системи в них. 

У ЗАКЛАДІ ПІСЛЯДИПЛОМНОЇ ПЕДАГОГІЧНОЇ ОСВІТИ

Мета статті: визначити й охарактеризувати основні елементи внутрішньої системи забезпечення якості освіти у закладах післядипломної педагогічної освіти.

Виклад основного матеріалу. Оскільки управління якістю освіти як процес базується на основних принципах сучасної освітньої політики, то очевидно, що заклад освіти, зокрема і заклад післядипломної педагогічної освіти (ЗППО), має керуватися вимогами законодавства до побудови внутрішньої системи забезпечення якості освіти. Орієнтиром для побудови внутрішньої системи забезпечення якості освіти закладу післядипломної педагогічної освіти стають вимоги, виписані у Законі України "Про освіту", Національному стандарті України ДСТУ ISO 21001:2019 (ISO 21001:2018, IDT) Освітні організації. Системи управління в освітніх організаціях. Вимоги та настанови щодо застосування $[2,1]$.

Проаналізовані джерела та вимоги, досвід впровадження дають змогу структурувати внутрішню систему забезпечення якості освіти ЗППО за такими елементами, як: мета; принципи; основні завдання; функції; структура відповідальності; механізми забезпечення якості освіти; удосконалення освітньої діяльності, освітніх програм; інформаційне забезпечення освітньої діяльності; оцінювання слухачів курсів підвищення кваліфікації; документи, що регламентують управління якістю освітньої діяльності; забезпечення публічності інформації про ЗППО та освітні програми; забезпечення системи академічної доброчесності; забезпечення підвищення кваліфікації педагогічних та науковопедагогічних працівників ЗППО тощо. Таке структурування лягає в основу Положення про внутрішню систему забезпечення якості освіти ЗППО.

Насамперед варто визначитися з політиками внутрішньої системи тобто елементами, які спрямовують діяльність у сфері якості, - метою, принципами, завданнями - та виокремити процедури як сукупності взаємопов'язаних робіт для досягнення запланованого результату.

Цілеспрямованість внутрішньої системи забезпечення якості освіти ЗППО визначається формулюванням мети, якою може бути встановлення, підтримка функціонування та поліпшення механізмів якості освіти та якості освітньої діяльності.

Основними вихідними положеннями, принципами, на яких базуватиметься внутрішня система забезпечення якості освіти ЗППО, стають: академічна доброчесність; відкритість до нової інформації; партнерська взаємодія; компетентність персоналу; відповідальність за результат; лідерство та ініціативність; орієнтація на замовника; узгодженість у прийнятті управлінських рішень тощо.

Досвід побудови внутрішньої системи забезпечення якості освіти у ЗППО дає підстави стверджувати, що суттєвим етапом їі впровадження $є$ визначення основних завдань (цілей), вона система має керуватись - це забезпечення якості освітньої діяльності та якості освіти; практико-орієнтоване підвищення кваліфікації педагогічних працівників закладів та установ освіти; побудова сучасного інформаційно забезпеченого освітнього середовища засобами дистанційних технологій; створення системи безперервного професійного розвитку персоналу; розвиток позитивного іміджу ЗППО тощо.

Зрозуміло, що такі завдання мають характер тактичних цілей, які варто деталізувати шляхом розроблення функціонального набору внутрішньої системи забезпечення якості освіти ЗППО. Такі функції розглядаються як оперативні цілі, способи і заходи діяльності, процедури спрямовані на реалізацію завдань. 3 нашої точки зору, виправданими тут $є$ високий ступінь деталізації, уточнювальний характер, максимальнараціональність, насиченість змісту, наявність дублювання деяких формулювань тощо.

У нашому баченні до таких функціональних процедур варто віднести: розподіл повноважень між структурними підрозділами 3 питань забезпечення якості освіти; оптимальне використання внутрішніх горизонтальних зв'язків для налагодження ефективної комунікації; узгодженість у прийнятті рішень відповідно до розроблених норм; впровадження практикоорієнтованого підвищення кваліфікації педагогічних працівників закладів та установ освіти; забезпечення можливості вільного вибору освітніх програм; диверсифікація освітніх програм за темами, формами проведення, термінами проведення, обсягами; регулярність збору інформації щодо якості освітньої діяльності; забезпечення академічної доброчесності; сприяння безперервному професійному розвиткові педагогічних та науково-педагогічних працівників; розроблення навчальних матеріалів, у тому числі електронних, для забезпечення проведення курсів підвищення кваліфікації; моніторинг результатів організації та проведення курсів підвищення кваліфікації; урахування результатів опитування під час опрацювання змісту освітніх програм; апробація навчальних матеріалів шляхом публікацій у фахових та методичних джерелах; впровадження інноваційних технологій та методів 


\section{ОСОБЛИВОСТІ ВПРОВАДЖЕННЯ ВНУТРІШНЬОЇ СИСТЕМИЗАБЕЗПЕЧЕННЯ ЯКОСТІ ОСВІТИ}

У ЗАКЛАДІПІЛЯДИПЛОМНОЇ ПЕДАГОГІЧНОЇ ОСВІТИ

роботи зі слухачами курсів підвищення кваліфікації; сприяння побудові індивідуальної освітньої траєкторії педагогічного працівника засобами організації курсів підвищення кваліфікації; публічна діяльність 3 просування у зовнішньому середовищі інформації з питань освітньої політики, освітніх тенденцій; комунікація iз зовнішніми та внутрішніми стейкхолдерами; розвиток інформаційно забезпеченого освітнього середовища закладу засобами дистанційних технологій; розвиток системи командної взаємодії структурних підрозділів тощо.

Зазначені вище процедури ілюструють загальні характеристики діяльності ЗППО. Уважаємо, що функціональний набір залежить від масштабу діяльності, що є специфічною ознакою окремого ЗППО.

Значне місце у впровадження внутрішньої системи забезпечення якості освіти належить процедурі вибудовування структури відповідальності за іiі реалізацію. Встановлення такої процедури $€$ необхідним заходом, оскільки фіксує делегування такої відповідальності, а не тільки повноважень, встановлює організаційні зв'язки підпорядкування, додатково формалізує напрями виконання процедур, а відтак конкретизує їх. Зрозуміло, що відповідальність за реалізацію внутрішньої системи забезпечення якості освіти покладається не тільки на робочі органи управління, керівників ЗППО, керівників структурних підрозділів, а й на колегіальні органи - вчена рада, науковометодична рада, рада $з$ якості освіти ЗППО тощо. У цьому контексті слід зазначити, що документування такої відповідальності відбувається шляхом введення відповідних змін у положення про структурні підрозділи та колегіальні органи, у посадові інструкції посадових осіб, виправданим може бути створення окремого структурного підрозділу, наприклад, Центру забезпечення якості освіти ЗППО тощо. Водночас, чільне місце відводиться Положенню про внутрішню систему забезпечення якості освіти ЗППО, у якому представлена структура відповідальності як окремий розділ.

Виведення забезпечення якості освіти в окрему процедуру у розбудові внутрішньої системи забезпечення якості освіти ЗППО має на меті розмежувати їі реалізацію за основними напрямами - якість управлінських процесів та якість процесів організації та провадження курсів підвищення кваліфікації. Доречне використання універсального управлінського циклу для представлення сукупності процесів, спрямованих на забезпечення якості управління. Тому до забезпечення якості управлінських процесів у
ЗППО нами віднесено: якість аналізу потреб і очікувань зацікавлених сторін; якість планування процесів освітньої діяльності; якість організації курсів підвищення кваліфікації; якість стимулювання та мотивації кадрових i матеріально-технічних ресурсів; якість контрольних заходів і процесів самооцінювання тощо.

До забезпечення якості процесів організації та провадження курсів підвищення кваліфікації у ЗППО віднесено: якість реагування на потреби і очікування зацікавлених сторін; якість вимог щодо критеріїв оцінювання змісту та структури освітніх програм підвищення кваліфікації і навчальних планів курсів підвищення кваліфікації; якість викладання на курсах підвищення кваліфікації (опитувальник щодо якості освітньої діяльності); якість навчально-методичних матеріалів (навчально-методичні комплекси до освітніх програм підвищення кваліфікації); якість регламентних вимог у ЗПО.

Окремо до процесів забезпечення якості освіти у ЗППО слід віднести рішення керівників структурних підрозділів з питань вдосконалення та розвитку внутрішньої системи забезпечення якості освіти у ЗППО.

Удосконалення якості освітньої діяльності може бути віднесено до процедур внутрішньої системи забезпечення якості освіти. Реалізація процедури удосконалення спрямована на підтримку функціонування алгоритмів та механізмів відстеження досягнутих результатів, аналізу освітніх програм тощо. Акцентуємо увагу на тому, що має бути передбачено виконання низки повноважень 3 удосконалення якості освітньої діяльності, які донедавна не були властиві робочим органам ЗППО, тому модернізація їх діяльності $\epsilon$ умовою належного вирішення. В управлінні ЗППО задля модернізації та оптимізації діяльності можливе використання процесів зміни структури або зміни змісту діяльності окремих структур. Очевидно, що зміна структури, пов'язана з подоланням значної кількості формальних процедур, є прерогативою засновника, потребує значного часового проміжку тощо, тому оновлення змісту діяльності структурних підрозділів є більш оперативним шляхом реагування на нові умови і потреби. На цій підставі створення центру забезпечення якості освіти у складі окремого підрозділу є, по-перше, вимогою управління якістю освітньої діяльності, а по-друге, дієвим механізмом внутрішньої системи забезпечення якості освіти.

Інформаційне забезпечення освітньої діяльності у складі процедур внутрішньої системи 


\section{ОСОБЛИВОСТІ ВПРОВАДЖЕННЯ ВНУТРІШНЬОЇ СИСТЕМИЗАБЕЗПЕЧЕННЯ ЯКОСТІ ОСВІТИ УЗАКЛАДІПІЛЯДИПЛОМНОЇ ПЕДАГОГІЧНОЇОСВІТИ}

забезпечення якості освіти розглядається як використання відкритих систем управління навчанням; електронних ресурсів на сайті ЗППО тощо. Варто ураховувати вимоги до інформаційного забезпечення освітньої діяльності згідно з п. 46 Постанови Кабінету Міністрів України від 30 грудня 2015 р. № 1187 (в редакції Постанови Кабінету Міністрів України від 24 березня 2021 р. № 365) Ліцензійні умови провадження освітньої діяльності щодо забезпечення доступу здобувачів освіти до електронних версій необхідних підручників, навчальних посібників, конспектів лекцій тощо (або відповідного електронного ресурсу) [6].

Оцінюванню слухачів курсів підвищення кваліфікації у внутрішній системі забезпечення якості освіти відведено значне місце, оскільки оцінювання $є$ способом аналізу досягнутих результатів, визначенням проблемних аспектів навчання та викладання тощо. Процедура оцінювання передбачає розроблення низки необхідних документів, які відображають основні механізми, логіку і послідовність здійснення необхідних дій.

Підвищення кваліфікації педагогічних та науково-педагогічних працівників ЗППО розглядається як складова процесу безперервного професійного розвитку та умова якості освітньої діяльності. Виокремлення цього елемента у вигляді окремої складової внутрішньої системи забезпечення якості освіти дає підставу акцентувати увагу на удосконаленні загальних та професійних компетентностей, необхідних для здійснення наукової, навчальної, методичної та організаційної діяльності у ЗППО. Підвищення кваліфікації науково-педагогічних і педагогічних працівників у ЗППО регламентується окремими Порядками підвищення кваліфікації та визнання результатів підвищення кваліфікації науковопедагогічних працівників і педагогічних працівників ЗППО згідно з вимогами Постанови Кабінету Міністрів України від 21 серпня 2019 р. № 800 “Деякі питання підвищення кваліфікації педагогічних і науково-педагогічних працівників” [7].

Висновок. Управління якістю освіти розглядається як провідна ідея управління ЗППО, передбачає розроблення механізмів задля підвищення якості освітньої діяльності та якості освіти. Внутрішня система забезпечення якості освіти ЗППО, побудована 3 урахуванням сучасного стану вимог, нових практичних підходів, стає суттєвим елементом управління якістю освіти. Особливості розроблення структури внутрішньої системи забезпечення якості освіти
ЗППО полягають в урахуванні основних процесів діяльності закладу, спрямованих на задоволення потреб педагогічних працівників закладів загальної середньої дошкільної, позашкільної освіти у підвищенні кваліфікації.

\section{ЛITEPATУРA}

1. ДСТУ ISO 21001:2019 Освітні організації. Системи управління в освітніх організаціях. Вимоги та настанови щодо застосування (ISO 21001:2018, IDT) / Технічний комітет стандартизації “Системи управління якістю” (ТК 189).

2. Закон України "Про освіту”. URL: https:// zakon.rada.gov.ua/laws/show/2145-19\#Text

3. Лукіна Т. О. Управління якістю освіти. Енциклопедія освіти / АПН України ; гол. ред. В. Г. Кремень. Київ : Юріном Інтер, 2008. С. 945-947.

4. Освіта дорослих : короткий термінологічний словник / авт.-упоряд. Лук’янова Л. Б., Аніщенко О. В. Київ ; Ніжин : Видавець ПП Лисенко М. М., 2014. 108 с.

5. Пастовенский О., Ренькас Б. Примірне положення про внутрішню систему забезпечення якості освіти в закладі загальної середньої освіти. Народна освіта. 2019. № 3 (39).

6. Постанова Кабінету Міністрів України від 30 грудня 2015 р. № 1187 (в редакції постанови Кабінету Міністрів України від 24 березня 2021 р. № 365) Ліцензійні умови провадження освітньої діяльності. URL: https:// zakon.rada.gov.ua/laws/show/365-2021-\%D0\%BF\#Text

7. Постанова Кабінету Міністрів України від 21 серпня 2019 р. № 800 “Деякі питання підвищення кваліфікації педагогічних і науково-педагогічних працівників”. URL: https://zakon.rada.gov.ua/laws/show/ 800-2019-\%D0\%BF\#Text

8. Системи управління якістю. URL: https:// www.pharmencyclopedia.com.ua/article/546/sistemiupravlinnya-yakistyu.

\section{REFERENCES}

1. DSTU ISO 21001: 2019 Osvitni orhanizatsiyi. Systemy upravlinnya $\mathrm{v}$ osvitnikh orhanizatsiyakh. Vymohy ta nastanovy shchodo zastosuvannya [Educational organizations. Management systems in educational organizations. Requirements and guidelines for use] (ISO 21001: 2018, IDT) / Technical Committee for Standardization of Quality Management Systems (TC 189). [in Ukrainian].

2. Zakon Ukrayiny "Pro osvitu" [Law of Ukraine "On Education"]. Available at: https://zakon.rada.gov.ua/laws/ show/2145-19\#Text. [in Ukrainian].

3. Lukina, T. O. (2008). Upravlinnya yakistyu osvity [Education quality management]. Encyclopedia of Education. (Ed.). V. H. Kremen. Kyiv, pp. 945-947. [in Ukrainian].

4. Osvita doroslykh (2014): korotkyy terminolohichnyy slovnyk [Adult education]. (Eds.). Lukyanova L. B. \& Anishchenko O. V. Kyiv, 108 p. [in Ukrainian].

5. Pastovenskyy, O. \& Renkas, B. (2019). Prymirne polozhennya pro vnutrishnyu systemu zabezpechennya yakosti osvity $\mathrm{v}$ zaklady zahalnoyi serednoyi osvity 


\section{МЕТОДИЧНІ АСПЕКТИГРАФІЧНОЇ ПІДГОТОВКИМАЙБУТНІХІНЖЕНЕРІВ-МЕХАНІКІВ ЗАСОБАМИ КОМП'ЮТЕРНОГО МОДЕЛЮВАННЯ}

[Indicative provision on the internal system of quality assurance of education in general secondary education]. Public education. No. 3 (39). [in Ukrainian].

6. Postanova Kabinetu Ministriv Ukrayiny vid 30 hrudnya 2015 r. № 1187 (u redaktsiyi postanovy Kabinetu Ministriv Ukrayiny vid 24 bereznya 2021 r. № 365). Litsenziyni umovy provadzhennya osvitnoyi diyalnosti [Resolution of the Cabinet of Ministers of Ukraine No 1187 Licensing conditions for educational activities]. Available at: https://zakon.rada.gov.ua/laws/show/3652021-\%D0\%BF\#Text. [in Ukrainian].
7. Postanova Kabinetu Ministriv Ukrayiny vid 21 serpnya 2019 r. № 800 “Deyaki pytannya pidvyshchennya kvalifikatsiyi pedahohichnykh i naukovo-pedahohichnykh pratsivnykiv" [Resolution of the Cabinet of Ministers of Ukraine No. 800 Some issues of professional development of pedagogical and scientific-pedagogical workers] Available at: https://zakon.rada.gov.ua/laws/show/8002019-\%D0\%BF\#Text. [in Ukrainian].

8. Systemy upravlinnya yakistyu [Quality management systems]. Available at: https://www.pharmencyclopedia.com.ua/ article/546/sistemi-upravlinnya-yakistyu. [in Ukrainian].

Стаття надійшла до редакції 11.10.2021

УДК 378.04:62]:378.091.39:004.94

DOI:

Владислав Бойко, кандидат педагогічних наук, доиент кафедри будівництва та ичивільної інженерії Національний університет

"Полтавська політехніка імені Юрія Кондратюка"

Лариса Гриценко, кандидат педагогічних наук, доцент, дочент кафедри теорії і методики технологічної освіти Полтавського національного педагогічного університету імені В. Г. Короленка

\section{МЕТОДИЧНІ АСПЕКТИ ГРАФІЧНОЇ ПІДГОТОВКИ МАЙБУТНІХ ІНЖЕНЕРІВ- МЕХАНІКІВ ЗАСОБАМИ КОМП'ЮТЕРНОГО МОДЕЛЮВАННЯ}

У статті представлено методичні аспекти графічної підготовки майбутніх інженерів-механіків у закладах вищої та професійно-технічної освіти. Вказується необхідність створення й застосування в освітньому проиесі інформаиійно-освітнього середовищза засобами комп 'ютерного моделювання. Виділено дидактичні принципи та педагогічні умови, щэо є складовими методичної системи викладання предмету креслення. Розглянуто нормативно-правові документи (Концепція розвитку професійної освіти і навчання 6 Украӥні (2012-2020), Національна стратегія розвитку освіти в Украӥні (2012-2021), Закони Украйни "Про вищу освіту” (2016), “Про освіту” (2016), “Національна стратегія розвитку освіти в Украӥні на період до 2021 року”). Авторами розвідки для розв'язання завдань та розкриття проблеми запропоновано власну кониепиію графічної підготовки майбутніх інженерів-механіків засобами комп 'ютерного моделювання.

Ключові слова: методика; комп'ютерне моделювання; графічна підготовка; майбутні інженеримеханіки; інформаційно-освітнє середовище; дидактичні принциии; педагогічні умови.

Puc. 1. Лim. 13.

Vladyslav Boyko, Ph.D.(Pedagogy), Associate Professor of the Construction and Civil Engineering Department, National University "Poltava Polytechnic named after Yuri Kondratyuk"

Larysa Hrytsenko, Ph.D.(Pedagogy), Associate Professor, Associate Professor of the Theory and Methods of Technological Education Department, Poltava Volodymyr Korolenko National Pedagogical University

\section{METHODICALASPECTS OF GRAPHIC TRAINING OF FUTURE MECHANICAL ENGINEERS BY MEANS OF COMPUTER MODELING}

The article presents methodological aspects of graphic training of future mechanical engineers in institutions of higher and vocational education. The necessity of creation and application in the educational process of information-educational environment by means of computer modeling is indicated. The didactic principles and pedagogical conditions that are components of the methodical system of teaching the subject of drawing are highlighted. Regulatory and legal documents (Concept of development of vocational education and training in Ukraine) (2012-2020), National strategy of development of education in Ukraine (2012-2021), Laws of Ukraine "On higher education" (2016), "On education" (2016) are considered, "National Strategy for Education Development in Ukraine until 2021"). The authors of the research proposed their own concept of graphic training of future mechanical engineers by means of computer modeling to solve problems and solve the problem.

In the theory of education and training at the present stage of their development, paradigmatic approaches to the organization of vocational training, corresponding didactic principles, principles of industrial training and 